\title{
Electronic Banking Transactions and Their Effects on the Performance of Selected Commercial Banks in Cameroon
}

\author{
Anselm Ngwa N. \\ University of Buea, PO box 63,Buea Cameroon
}

\begin{abstract}
This paper focuses on the electronic banking transactions and how these transactions affect the performance of banks. Using a series of proxy variables for e-banking adoption, the study seeks to verify how the implementation of e-banking by commercial banks affects the profitability of the banks. The data for the study was got from the financial records of selected commercial banks in Cameroon as well as from the data base of the Central bank of Cameroon (BEAC), between 2006 and 2018. In analyzing the data, regression analysis method was used to determine the impact of MMT, ATM, PPV, IFR, and DTF on the ROA of the banks. Other analytical methods used include, correlation analysis and descriptive analysis. The findings of the study reveal that MMT, DTF and EPT all have positive impacts on ROA, while PPV and IFR have negative impacts on the ROA of the banks. The overall results however indicate that e-banking transactions have a significant impact on the profitability of banks. The study recommends that banks should increase the level of direct participation into the Mobile banking market. In addition, the commercial banks should increase international transfer transactions, Electronic payment terminals as well as improve on the level of e-banking technology and innovation.
\end{abstract}

Key words: Electronic Banking, Performance, Commercial banks, Cameroon

DOI: $10.7176 /$ RJFA/11-8-11

Publication date: April $30^{\text {th }} 2020$

\section{Introduction}

The Cameroon banking sector is the largest in the CEMAC sub region representing about $52 \%$ of the overall banking sector of the region. The banking sector has undergone a series of stages as part of the evolution of its financial sector. The IMF Report (2001), revealed that the Cameroon banking system suffered a massive set back by 1994 due to the devaluation of the country's currency by 50\% in January 1994 followed by the slashing of public worker salaries by $50 \%$. As a result, deposits and investments were greatly reduced which consequently, had a negative effect on the system resulting to numerous shocks on the banking system? This explains why by 1980s the banking system underwent massive crisis which led to the liquidation of most of the existing banks in the system.As part of the consequence,between 2012 and 2016 a number of acquisitions and merger took place within the Cameroon banking sector; Hence, UBC merged with Oceanic Bank 75\% / 25\%( 3:1) shares ownership. By 2016, due to some operational difficulties, Oceanic bank share was acquired by Ecobank Cameroon which remains the same situation till date. In addition within the same period, Amity bank was completely acquired by Atlantic Bank Cameroon.

Furthermore, Jeune Afrique (2017) notes that as at 2017, the Cameroon banking system had a total of 14 operational commercial banks which include, Afriland First Bank, Atlantic Bank Cameroon'Banque International du Cameroun pour l'Epargne et le Crédit (BICEC),BGFI Bank Cameroon, ScbCameroun, Citibank, Commercial Bank of Cameroon, Ecobank Cameroon - Acquired Oceanic Bank Cameroon, National Financial Credit Bank (NFCB) Société Commerciale de Banque du Cameroun - (Formerly SCB Credit Agricole), Societe Generale des Banques au Cameroun (SGBC) Bank, Union (UBC) United Bank for Africa (UBA). Also, a total of 7 commercial banks in Cameroon are classified amongst the first 200 banks in Africa. In addition, the said 7 commercial banks also appear amongst the top 15 position in the 50 most efficient banks in the CEMAC Zone.

Nevertheless, focusing more specially on e-banking in Cameroon, it is worth noting that electronic banking transactions are still relatively at its infancy in Cameroon, compared to other African countries like Nigeria, South Africa, Kenya, and Zimbabwe, which embraced e-banking many decades ago. Before 1997, only face-to-face banking was applicable in Cameroonian banks, as there were very little electronic banking transactions. However, with the need to meet up with globalisation and modern banking techniques, banks in Cameroon have also increases their level of implementation of e- banking transactions over the past decade.

The increase in the fraud levels in banks has also coincided with innovation in banking and manual banking (face-to face banking) becoming electronic or virtual banking. The increase use of technology in the Cameroon banking sector has resulted to the banks having no option but to embrace the new innovation in banking, electronic banking. Hence from face-to-face banking, most banks now use internet (online) banking. All the banks in Cameroon with the most recent being NFC bank now offer ATM services to its customers and most of the commercial banks offer other card services such credit cards, debit cards, prepaid cards ,I cards and so on. The most innovative in all the e-banking products is Mobile Phone Banking which is competing with other forms of ebanking such as ATMs, Prepaid Cards, and Point of Sale Terminals. 
Moreover, since 2012, one major development in E-banking in Cameroon is mobile banking; mobile banking was introduced by the mobile telephone companies MTN and ORANGE which operate within the Cameroon industry. But the introduction of this form of e-banking has been made possible with the assistance of many banks such as Afriland first bank, Eccobank and more recently, UBA bank which was very quick in implementing the mobile banking. The speed and low cost to create mobile money accounts has attracted many people to create Mobile money accounts complementing the other forms of e-banking products.

In addition, use of Card services has also become very prominent amongst customers of banks in Cameroon. For instance, Ecobank Cameroon offers card services such as credit cards, debit cards, prepaid cards and ATM CARDS. In addition, to the card types mentioned above, Afriland first bank has the I-Card which facilitates transactions between suppliers and retailers. In addition, BICEC offers the master cards and visa cards as well as the E-Pay Box which enables customers to receive payments using any Visa card of any bank. In the case of internet banking, most of the banks in Cameroon especially UBA, Ecobank, Afriland First banks and Union Bank of Cameroon (UBC) make use of internet banking channels.ATM usage represents the main means of carrying out banking transactions as over $65 \%$ of bank customers at least have an ATM card.

That notwithstanding, the increased use of e-banking has brought about some problems which the banks face in the implementation of e-banking in their operations. The greatest threat to the banks is the development of Mobile banking which as previously mentioned, is largely operated by non bank institutions like the mobile phone companies. The problem here is that Mobile banking accounts are basically current accounts, and cost averagely 500FCFA or even free in some cases to create. But bank current accounts cost averagely 25000FCFA and 50,000FCFA to create a savings account in a commercial bank (Ecobank annual report (2016). Thus, the high expenses involved in creating bank accounts compared to Mobile banks accounts has the probability of causing the banks to lose future potential customers of the bank. This is already the case, given that about $90 \%$ of university students are obliged to have mobile banking accounts for their respective school related payments. This implies that the banks may have lost a huge part of their customer base, especially as an average student cannot afford 25000 of 50,000 to create a bank account. Worse still is the fact that the banks charge averagely 3500 FCFA monthly on their current accounts, meanwhile a mobile money account holder has no monthly charge on his accounts. Hence, from all indications a huge bank income can be lost the more customers switch to mobile banking.

In addition, worth noting is the problem which arises from the fact that most electronic banking transactions have a link with each other. For instance, a new Ecobank and Afriland First bank mobile phone applications make it possible for withdrawals to be undertaken from customer Current accounts and in some case Savings accounts using the ATM service. In addition the use of electronic point of sales terminal as prepaid cards makes it possible for direct debits to be carried out on customers' accounts on their behalf by the banks for payments terminals. Hence this link in electronic service outlets may also imply an increase in the fraud levels and insecurity on accounts, as well as bank cost of service provision. All these factors have a probability of affecting bank profit negatively.

Furthermore, electronic banking has caused most of the banks to start restructuring in order to adapt to the technological changes that are taking place in global banking. This restructuring has recently been in the form of shutting down branches of banks and increasing the ATM outlets and many other electronic transaction facilitators, like what Ecobank is currently doing. The problem faced by the banks here is that the most profitable aspect of banks is loans, while the most profitable aspect of the mobile banking companies is not loans. Thus, shutting down the branches may increase the level of loans default and risk on the customers' accounts. This is because the concept of Know Your Customer (KYC) becomes almost nonexistent, as customers now deal only with digital means with very little face to face contact. This might cause both the banks and the customers to lose huge amounts on their accounts since even though transactions are faster and arguably more efficient security cost may also be high which may affect bank income negatively.

Therefore, the growth of e-banking may just have a lot of aspects which are not yet known to the banks, but which may cause a lot of problems on the bank portfolio as banks continue to invest in the new found digital banking. Thus, it is on this basis that this current study sets out as objective to; examine the extent to which ebanking transactions affects profitability of commercial banks.

\section{Literature Review}

A lot of literature has been reviewed on this area of study with numerous empirical findings having been made especially given that this area of study is a contemporary area which has consistently been important for the banks to understand the dynamics of e-banking.

In line with the above, Haider et al (2011) consider electronic banking to be the use of the internet as a delivery mode for the provision of services like opening a deposit account, electronic bill payments and online transfers. These services can either be provided by the bank having physical offices and by creating a website and providing services through that or the services can be provisioned through a virtual bank as well. Internet is used as strategic and differentiating channel to offer high valued financial services, and complex products at lower cost without 
physical boundaries and to cross sell products like credit cards and loans. While Hosein (2012), views e-banking as an internet portal through which customers use different kinds of banking services, ranging from bills payments to making investments. Therefore, banks websites that offer only information on their pages without the option to make transactions are not qualified as online banking services.

From the perspective of the current study, electronic banking can be considered as a banking transaction system which makes use of electronically generated tools to be able to carry out banking transactions including opening of customer accounts, loans applications, verification of customer transactions and information provision to customers' transactions. It includes numerous channels of banking such as telephone banking and TV based banking. It also includes other offline payment means such as the use of credit cards, debit cards and ATM cards and other stored cards that are used for both cash out and cash in transactions. In a whole both online and online banking transactions are included in the concept of electronic banking.

However, numerous empirical studies have been carried out related to e-banking transactions. The studies have divergent views and findings on how e-banking affect the performance of institutions.

In line with the view above, Gayathri G and Suvitha K. (2018), carry out a study on the impact of information technology on the profitability of banks in india. The study uses a pooled data collected across banks in india. Both the random and fixed effects models were used and a descriptive statistical analysis method was implemented alongside a regression analysis. The results of the study indicated that IT expense, marketing expenses; printing expenses are all positive while depreciation expenses were the only negative variable. The results also revealed that the random effect model is significant on pooled data than the fixed effect model.

Furthermore, Loide D and Teresia K (2018), investigate the impact of e-banking on commercial banks' performance in Namibia. The study uses time series data that covers the period 2012 to 2015.E-banking Variables such electronic funds transfers, interbank settlement system, Cheaques, and ROE as the dependent variable. Descriptive statistics methods and simple regression anaylsis was used to analyse the data and the results of the study reveal that previous levels of interbank settlements explain ROE better than current. Also electronic funds transfers and Cheques have a significant effect on profitability.

On their part, Shaohua yang et al (2018), carry out a study titled 'Does Electronic Banking Really Improve Banks Performance? The authors use data from 5 banks in China covering the period 2003-2013. Secondary data collection method was used with major variables involving ROA ROE and operating Margin. A descriptive statistics methods was used alongside the t-test to test for the difference in the before and after e-banking adoption effect. The results of the study show that there is significant different in effect of the performance indicators between before and after adoption of e-banking. There is a significant increase in the profitability of the banks over that period.

Moreover, Jean Bosco (2017), studies on 'The Impact of Mobile Banking on financial Performance of Microfinance in Rwanda. The study focused on identifying the volume of transactions and products of mobile banking services and the to measure the relationship between transaction volume and MFI performance. The author uses both a qualitative and quantitative research method. Descriptive statistics was used alongside correlation and regression analysis to analyse the data for the study. The findings show that there is a positive correlation between financial performance indicators before and after adoption of e-banking. The authors recommended lower transaction charges on mobile transactions.

On his part, Joseph M (2017) investigates the impact of electronic banking on the profitability of commercial banks in Kenya. The Author uses a descriptive research design. The sample was made up of 43 commercial banks in operations. In addition secondary data was used for the study and data was obtained from various central banks. A multiple regression analysis method was used to analyse the data and the findings indicate that there a positive and significant relationship between ATM transactions, POS transactions and bank profitability. The study recommended that banks should increase their ATM networks and encourage POS terminals.

In addition, Fatma D (2017), analyses the relationship between financial innovation and the performance of Turkish banks. The study uses mobile banking, credit cards and online banking as main variables of the study. Data for the study was achieved from official sources between 2006Q1 and 2015Q2.A simple regression analysis alongside descriptive statistics was used to analyse the data for the study. The results of the study reveal that only credit card usage has a significant positive impact on return on assets (ROA), return on equity ROE and Net interest margin. This study is also limited in the sense that it also ignores pre-adoption era and considers only post adoption era of e-banking effects. In addition the e-banking variables of the study are limited, for instance funds transfers transactions are completely ignored.

On his part, Fonchamnyo (2012) studies the perception of E-banking Adoption in Cameroon. The author uses the extended TAM which was assessed using a sample survey of 210 customers. The psychometric properties of the data were investigated using the estimation of internal consistency reliability and the convergent and discriminate validity of the instrument items. The results estimated using a path regression analysis showed that perceived security, trust, cost of service, usefulness, and accessibility have significant influenced on customer's attitudes and hence adoption of e-banking. The results further showed that characteristics such as age, education 
and marital status have significant influence on customer's attitude.

Nevertheless, all the other studies above with the exception of the study of Fonchamyo, are not based on Cameroon banking system but on the banking system of other countries. In addition, the study by Fonchamyo on e-banking in Cameroon is also limited given that it focuses only on perception and behaviour of customers towards adoption of e-banking and does not evaluate the effects on the profitability of the banks. In addition the study does not take into consideration the actual adoption variables such as Electronic funds transfers, Electronic payment terminals, Mobile banking, to name a few. Hence the study is only pre-adoption focused and does not take into consideration post-adoption issues. However, this current study considers the post adoption electronic banking adoption transactions and how they affect the profitability of the commercial banks.

\section{Methodology}

This study makes use of secondary data. Data for the study was got from the annual financial transaction records of four major commercial banks in Cameroon which included; Ecobank Cameroon, Afriland First Bank, Banque International du Cameroun pour l'Epargne et le Crédit (BICEC) and Societe Generale Cameroun (SGC),. These banks were chosen based on the fact that they represent the top 4 largest banks in Cameroon in terms of capital, and as such they represent the level of concentration of the banking system. Other aspects of the data were collected from the Cameroonian central bank, BEAC, especially data related to payments services and mobile money transactions. In addition these banks are amongst the most innovative banks in Cameroon and have the most efficient mobile banking services, electronic payments terminals and card services. In addition the secondary data was quarterly data which covered the period covered the period 2012-2018.

\section{Model Specification}

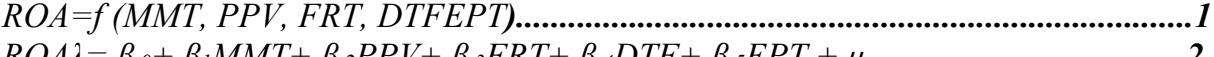

$R O A \lambda=\beta_{0}+\beta_{1} M M T+\beta_{2} P P V+\beta_{3} F R T+\beta_{4} D T F+\beta_{5} E P T+\mu \ldots \ldots \ldots . . \ldots \ldots \ldots . . . . . . . . .2$

Appriori Expectations: $\beta_{1>0,}, \beta_{2>0}, \beta_{3>0}, \beta_{4>0}, \beta_{5>0}$

Where;

ROE= Return on Assets: Refers to the total amount of profits generated by the assets of the bank. Measured as Net Income/Total Assets.

Predictor Variables

MMT= Mobile Money transactions: This refers to the total volume of transactions, cash deposits and withdrawals within the bank resulting to Mobile money transactions.

PPV= Prepaid Cards: This is the total net value of transactions carried out directly with the bank using card such as ATM and debit cards.

IFR= Foreign/international Transactions: This refers to the net value of funds transferred out of and into the country thorough the banking system.

DTF= Domestic Funds Transfers: This refers to the net volume of transactions in terms of funds transfers between banks at the national level.

EPT= Electronic Payments Terminal: This refers to the net cash value of transactions carried out using the points of sale terminals owned by the banks. 


\section{Results and Interpretation}

\section{Table 1: Regression Analysis Results}

\begin{tabular}{|c|c|c|c|c|c|c|c|c|}
\hline \multirow{2}{*}{\multicolumn{2}{|c|}{ Model }} & \multicolumn{2}{|c|}{$\begin{array}{c}\text { Unstandardized } \\
\text { Coefficients }\end{array}$} & \multirow{2}{*}{$\begin{array}{c}\text { Standardized } \\
\text { Coefficients } \\
\text { Beta }\end{array}$} & \multirow[t]{2}{*}{$\mathrm{T}$} & \multirow[t]{2}{*}{ Sig. } & \multicolumn{2}{|c|}{$\begin{array}{c}\text { Collinearity } \\
\text { Statistics }\end{array}$} \\
\hline & & B & $\begin{array}{l}\text { Std. } \\
\text { Error }\end{array}$ & & & & Tolerance & VIF \\
\hline \multirow[t]{6}{*}{1} & (Constant) & -.445 & .201 & & $\begin{array}{r}- \\
2.217\end{array}$ & .036 & & \\
\hline & MMT & .000 & .000 & -1.407 & $\begin{array}{r}- \\
7.099\end{array}$ & .000 & .033 & 30.084 \\
\hline & PPV & -.004 & .001 & -.219 & $\begin{array}{r}- \\
2.824 \\
\end{array}$ & .009 & .217 & 4.608 \\
\hline & IFR & -.044 & .009 & -.587 & $\begin{array}{r}- \\
4.695\end{array}$ & .000 & .084 & 11.976 \\
\hline & DTF & .361 & .040 & 2.323 & 9.035 & .000 & .020 & 50.647 \\
\hline & EPT & .008 & .018 & .148 & .475 & .639 & .013 & 75.007 \\
\hline
\end{tabular}

a. Dependent Variable: ROA

Model Summary

\begin{tabular}{|c|c|c|c|c|}
\hline Model & $\mathrm{R}$ & $\begin{array}{l}\mathrm{R} \\
\text { Square }\end{array}$ & Adjusted R Square & Std. Error of the Estimate \\
\hline 1 & $.983^{\mathrm{a}}$ & .966 & .960 & .02154 \\
\hline
\end{tabular}

Table 1 above represents the results of the regression analysis which was conducted to determine the effects of e-banking transactions on the profitability of banks. Therefore as seen from the table mobile money transactions MMT have a negative effect on the return on assets (ROA). This is indicated by the negative beta coefficient of 1.407. This results imply that a lunit increase in mobile money transactions of banks leads to 1.41 drop in the ROA of banks. In other words the banks are rather facing a drop in profitability implementing mobile money transactions. This result is so probably due to the fact that most of the banks have not fully incorporated the benefits of Mobile money into their transactions are still using Mobile money as a counter policy to the main Mobile money service providers MTN and Orange. In fact the banks are only secondary beneficiaries in the transactions given that all the account belongs to the MTN and Orange even though held at the banks, and despite the introduction of phone apps that enable direct transfers of funds from bank accounts to customer accounts, the benefits are still very minimal and the banks can only break even. Worth noting is the fact that this result is significant at $5 \%$ level of significance given the $\mathrm{p}$-value of .000 which is less than 0.05 .

The results also show a negative effect of prepaid cards (PPV) transactions on profitability (ROA). This is seen from the negative coefficient of -.219.This implies that a 1unit increase in prepaid card transactions would lead to a -.219 unit drop in the profitability of that banks. This result is so probably due to the fact that most of the banks transactions such as ATM cards are cash withdrawal transactions and generally cash withdrawals have negative effects on the banks liquidity portfolio given that it reduces the bank's ability to give out loans and generate interest from the cash. In addition most of the prepaid card accounts are current accounts in nature and as such yield very little to the bank comparatively to savings accounts which usually require per information before withdrawals are made. In fact the banks cannot use the current accounts to grant loans as well which further reduces the bank's profit generating potential the rough interest. Also prepaid cards have an issue cost, processing cost as well as maintenance cost, and coupled with the fact that the number of prepaid card subscribers and users is not very high and the costs still out way the benefits of the prepaid transactions. This is true despite the charges levied on customers by the banks. However the variable is insignificant at $5 \%$ level of significance. Indicating that PPV has an insignificant negative impact on the ROA of banks.

Moreover, the results on table also reveal that International funds transfers IFR has negative relationship with the profitability of the banks. This is seen from the negative coefficient of -.587. This implies that a 1unit increase in the international funds transfers leads to a -.587 units drop in the ROA of the banks. This results is so given that with the presence of multiple money transfer agencies such as moneygram, western union, world remit and many others, most of the bank's profitability got from wire transfers have drop drastically. In addition other alternative payments methods such as bitcoins and even both formal and informal Mobile money payments methods have drastically reduced the profits generating potential of banks from international transfers. In addition the bank also incurs transfers processing costs and coupled with the frequent fluctuations in international exchange rates also affects the banks foreign transactions portfolio negatively. In addition the issue of regulation is not left out as COBACs money laundering regulations have put a transfer's cap on foreign transactions which further reduces the bank's ability to generate enough profits from foreign transfers. As a result despite being more secured the 
bank wire transfers are relatively more expensive than other non-bank foreign transfer's agencies which work negatively on the banks. Worth noting is the fact that these result is significant at $5 \%$ level of significance given the p-value of 0.09 which is greater than 0.05 .

Furthermore, the regression results above show that interbank domestic funds transfer (DFT) has a positive impact on the profitability (ROE) of the banks. This positive relationship is seen from the positive coefficient of 2.323.This implies that a unit increase in the local interbank funds transfers increases the ROA of the bank by 2.323 units. This positive effect comes from the fact that interbank transfers initiated by both the banks themselves and/or customers generally carry a high charge which is relatively higher than the charges of other local money agencies. Interbank cash movement's initiated by the bank through cheaques payments and clearance as well as interbank ATM operating funds, as well as interbank lending usually generate some profits for the banks. In addition customers initiated interbank transfer's transactions such as standing order or direct debits carry high charges which have the potential to increase the profitability of the banks. Also the volume of interbank transfers is also less regulated compared to foreign bank transfers which thus allow the banks to be able to generate huge profits from transactions involving local funds transfers. This result related to this variable is significant at $5 \%$ level of significance given a p-vale of .000 which is less than 0.05 . The significance of this variable is indicative of the importance of local funds transfers to the bank profit portfolio.

In addition, electronic payments terminal is shown to have a positive effect on the profitability of the banks. This positive effect is seen from the positive beta coefficient of .148. This implies that a unit increase in the volume of electronic payment terminal transactions leads to a .148 unit increase in the level of profitability of the banks. This increase in bank profitability comes from the fact that most electronic payment terminals carry charges which the customers are required to pay. These terminals are also relatively less costly to run and require very little personnel input for them to be used. In addition the terminals are much closer to the users which make it easier for the transactions to be effected within a short period of time. In all, the usage of most of these terminals makes it possible for the bank to even outsource operators of the machines who are not core bank employees at a relatively lesser cost. However the result is insignificant at 5\% level given that the p-value of .639 is less greater than 0.05 .

Nevertheless, a close look at all the results on the table above reveals that most of the individual independent variables results are significant, for instance MMT, IFR and DFT are all significant at 5\% level of significance. However two of the variables are insignificant, for instance, PPV and EPT are all insignificant at 5\% level of significance. The insignificance of the variables is probably partly due to the low level of adoption of the e-banking technology by the banks. The reason for this low adoption is partly due to the fact that the internet penetration level is low and some of the technology are too expensive and require a high technical knowhow which some of the employees and customers may not be able to implement.

However despite the insignificance of some of the individual predictor variables, the adjusted $\mathrm{R}^{2}$ value of 0.96 indicates that the joint effect of the independent variables; MMT, PPV, IFR, DTF, and EPT on profitability is highly significant at $5 \%$ level of significance. In other words the adjusted $\mathrm{R}^{2}$ results imply that over $96 \%$ of changes or variability of profitability (ROA) is accounted for by the joint effect of the predictor variables. Hence only $4 \%$ of the variability in the dependent variable ROA is unexplained by the predictor variables. This $4 \%$ is captured by the residual term.

The residual term represents other factors other than the ones we have used in this model but which may also have an effect on profitability (ROA). Thus in all, the model fits the data effectively and the results got from this model can provide reliable and effective policy proposals. 
Table 2: Correlation Analysis Results

\begin{tabular}{|c|c|c|c|c|c|c|c|}
\hline \multicolumn{2}{|c|}{ (2) } & MMT & PPV & IFR & DTF & EPT & ROA \\
\hline \multirow[t]{3}{*}{ MMT } & $\begin{array}{l}\text { Pearson } \\
\text { Correlation }\end{array}$ & 1 & -.069 & -.329 & $.793^{* *}$ & $-.796^{* *}$ & -.193 \\
\hline & Sig. (2-tailed) & & .729 & .087 & .000 & .000 & .324 \\
\hline & $\mathrm{N}$ & 28 & 28 & 28 & 28 & 28 & 28 \\
\hline \multirow[t]{3}{*}{ PPV } & $\begin{array}{l}\text { Pearson } \\
\text { Correlation }\end{array}$ & -.069 & 1 & -.210 & -.076 & -.077 & -.303 \\
\hline & Sig. (2-tailed) & .729 & & .283 & .701 & .695 & .117 \\
\hline & $\mathrm{N}$ & 28 & 28 & 28 & 28 & 28 & 28 \\
\hline \multirow[t]{3}{*}{ IFR } & $\begin{array}{l}\text { Pearson } \\
\text { Correlation } \\
\end{array}$ & -.329 & -.210 & 1 & .261 & -.223 & -.140 \\
\hline & Sig. (2-tailed) & .087 & .283 & & .180 & .254 & .478 \\
\hline & $\mathrm{N}$ & 28 & 28 & 28 & 28 & 28 & 28 \\
\hline \multirow[t]{3}{*}{ DTF } & $\begin{array}{l}\text { Pearson } \\
\text { Correlation } \\
\end{array}$ & $.793^{* *}$ & -.076 & .261 & 1 & $-.978^{* *}$ & $.388^{*}$ \\
\hline & Sig. (2-tailed) & .000 & .701 & .180 & & .000 & .041 \\
\hline & $\mathrm{N}$ & 28 & 28 & 28 & 28 & 28 & 28 \\
\hline \multirow[t]{3}{*}{ EPT } & $\begin{array}{l}\text { Pearson } \\
\text { Correlation }\end{array}$ & $-.796^{* *}$ & -.077 & -.223 & $-.978^{* *}$ & 1 & $.483^{* *}$ \\
\hline & Sig. (2-tailed) & .000 & .695 & .254 & .000 & & .009 \\
\hline & $\mathrm{N}$ & 28 & 28 & 28 & 28 & 28 & 28 \\
\hline \multirow[t]{3}{*}{ ROA } & $\begin{array}{l}\text { Pearson } \\
\text { Correlation }\end{array}$ & -.193 & -.303 & -.140 & $.388^{*}$ & $.483^{* *}$ & 1 \\
\hline & Sig. (2-tailed) & .324 & .117 & .478 & .041 & .009 & \\
\hline & 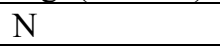 & 28 & 28 & 28 & 28 & 28 & 28 \\
\hline
\end{tabular}

The table above represents the correlation analysis results between the various e-banking adoption independent variables, MMT, PPV, IFR, DTF, EPT and the dependent variable ROA.

The results show that there is a negative relationship between MMT and ROA. This is seen from the negative coefficient of -.193. This implies that as the value of MMT increases the ROA of the institution reduces. This results is so given that the bank don't benefit much from the charges involved in the mobile money related transactions. Thus the profits generated from the transactions do not effectively counteract the expenses on the transactions.

In addition, Prepaid Cards Value (PPV) has a negative relationship with ROA. This is seen from the negative correlation coefficient of -.303.This indicates that an increase in the value of PPV leads to drop in the profitability of the banks. This is so given that most of the PPV are not very costly to get and the charges are not very high. For instance to carry out withdrawals from a different branch with the card is less expensive compared to carrying out withdrawals at the different branch with a counter cheque. Thus the banks face a reduced income with the use of cards. Also cards results to unstable liquidity portfolio of the banks.

The findings further show that foreign transactions (IFR) have a negative relationship with ROA. This is shown by the negative correlation coefficient of -.140. This implies that ROA of the banks reduces as the value of IFR transaction increase. This is so given that most card transactions are only debit or withdrawal oriented transactions. High cash withdrawals affect the banks loans portfolio negatively and consequently profitability is also negatively affected.

Moreover, the results also show that DTF has a positive relationship with ROA. This is shown by the positive coefficient of .388. This indicates that as the level of local interbank transfers increases the profitability of the banks increase. This is so given that local funds transfers transactions carry a high charge which contributes to the profitability of the banks. In addition some of the transactions such as salary transfers require a lot of processes and transactions which brings income to the banks.

Finally, the results also show that EPT is positively related to the ROA. This is seen from the positive correlation coefficient of the banks of .483. This implies that an increase in EPT leads to increase in the profitability of the banks. This result is probably due to the fact that the EPT have charges associated with the transactions. In addition the banks save in terms of low expenses on personnel as far as EPT transactions are concerned. This thus helps to have a positive impact on the profitability of the banks. 
Table 3: Descriptive Statistics Results

\begin{tabular}{|l|c|c|c|c|c|c|}
\hline & ROA & MMT & PPV & IFR & DTF & EPT \\
\hline Mean & 0.351667 & 196.2683 & 16.63333 & 2.609167 & 2.740000 & 4.195000 \\
\hline Median & 0.380000 & 39.12500 & 14.20000 & 3.195000 & 2.580000 & 3.850000 \\
\hline Maximum & 0.460000 & 965.0000 & 26.20000 & 3.980000 & 3.850000 & 6.480000 \\
\hline Minimum & 0.210000 & 14.20000 & 8.200000 & 0.300000 & 2.080000 & 1.330000 \\
\hline Std. Dev. & 0.104576 & 352.4371 & 7.053995 & 1.536955 & 0.615538 & 1.802363 \\
\hline Skewness & -0.303130 & 1.761006 & 0.421820 & -0.426729 & 0.749100 & -0.095444 \\
\hline Kurtosis & 1.351959 & 4.147830 & 1.546996 & 1.484629 & 2.303796 & 1.960499 \\
\hline & & & & & & \\
\hline Jarque-Bera & 3.083590 & 13.72208 & 2.822950 & 3.024740 & 2.729302 & 1.117001 \\
\hline Probability & 0.213997 & 0.001048 & 0.243783 & 0.220387 & 0.255470 & 0.572066 \\
\hline
\end{tabular}

The result from table 3 above shows that MMT has the highest standard deviation followed by PPV. The high standard deviation indicates that there is a high variability of the Mobile Banking transaction value over time compared to the other variables. This is probably due to the fact that it is a relatively new form of banking and most individual are not certain about the security of their transactions over time and hence transactions into and out of the accounts are performed at frequently given that it is a current account and cash can be moved into and out of at anytime. The availability of mobile app provided by the banks has also encouraged faster and easier transactions on these accounts.

In the case of PPV, the standard deviation is also relatively higher than the other variables with the exception of MMT. This is because similar to MMT the operations on Prepaid Accounts are mostly current account oriented and as such transactions on such accounts are more frequent. This also affects the variability of the banks liquidity portfolio.

Worth noting is the fact that the dependent variable ROA has the lowest standard deviation. This implies that the profitability of the bank is relatively stable. It also implies that the banks have a more predictable profitability portfolio which is also important to forecast both future liquidity risk and overall operational risk of the banks.

\section{Recommendations}

First, the management of banks should with the permission of the central bank (BEAC) have a direct participation in the Mobile money market. The banks can do so by also directly creating mobile money accounts as part of their normal bank accounts. Also the banks can also own mobile money kiosks operation by their personnel. This would increase their direct benefit from the charges paid by uses for using the accounts and hence increase their profits potential.

Secondly, the Management of Banks should increase the level of bank transfers over international agency transfers. This implies that the banks should convince customer to focus more of their international transfers especially outflows through bank transfers. This can be done by emphasizing on the security aspect of bank transfers which are usually relatively more secured.

In addition, banks management should increase Electronic Payment Terminals since has a positive impact on bank profitability. By increasing the payment terminal the banks can also increase the profitability given that the findings indicate that these terminals have a positive but insignificant effect on profitability, this increasing the number and volume can enable the banks benefit from a significant increase in their profitability in the future.

Lastly, the bank must ensure that the e-banking business moves currently with new technology. This implies that the banks should continuously improve their technology in order to create a positive image of their services in the minds of their customers. This would surpass competition and consequently create more anxiety in customers to use e-banking services and hence, boost profitability.

\section{Conclusion}

From the discussion above, it is clear that the issue of e-banking is a contemporary one that needs ongoing attention especially given the vast implications that it has on the banking system. However this current study has gone a long way to evaluate the dynamics of e-banking in banks and the possible effects it has on the management of banks. The study delves deeper into the various e-banking adoption variables and how each contributes to bank operations. If the recommendations from this study are effectively implemented by the banks and monetary authorities then the banks would be able to significantly increase their profitability through better management of their e-banking operations.

\section{References}

Aysel Gundogdu and Fatma Delvin, (2017), “Analysis of the Relationship between Financial Innovation and the 
Performance of Turkish Banking system". International Review of Economics and Management. Vol5, No 3, PP 16-32.

Dobdinga C. F, (2013), Customers Perception of E-banking Adoption in Cameroon: An Empirical Assessment of the Extended TAM. International Journal of Finance and Economics.Vol.5, No.1.pp.166-176.

Gayathri G and Suvitha K, (2018), "Impact of Information technology on Profitability of Banks in India, (2018), "International Journal of Pure and Applied Mathematics.Vol.118,No.20, PP.225-232.

Hussien Mohamed and Elyjoy Muthoni, (2018), "Effect of Internet Banking on Operational Performance of Commercial Banks in Nakuru country,Kenya. International Journal of Economics, Finance and Management Sciences. Vol 6, No.2, PP 60-65.

Ibrahim Hussien and Muneer Abbad, (2018), Antecedents and Adoption of E-banking in Bank Performance. The Perspective of Private Bank Employees. Interdisciplinary of Information, Knowledge and Management.Vol.13, No.1,pp 362-381.

Jean Bosco,(2017), "Impact of Mobile Banking on Financial Performance of Unguka Microfinance Bank Ltd,Rwanda. Global Journal of Management and Buisness.Research.Vol 17, No 4.

Joseph Vekya,(2017), "Impact of Electronic Banking on the Profitability of Commercial Banks in Kenya". Journal of Technology and Systems.Vol.1, No.1, pp.18-39.

Loide Davis and Teresia Kaulihowa, (2018), "The Impact of E-banking on commercial Banks' Performance in Namibia". International Journal of economics and Financial Research.

Shaohua Yang,Zeyun Li, Yaxin Ma, Xingxing Chen, (2018), "Does Electronic Banking Really Improve Bank Performance? Evidence in China”. International Journal of Economics and Finance, Vol.10,No.2, pp.82-94. 